\title{
Göç Kuramları ve Suriye Göçü Üzerine Bir Değerlendirme $^{1}$
}

\author{
DOI: 10.26466/opus.546737 \\ *
}

\section{Celal İnce*}

* Dr. Öğr. Üyesi, Bitlis Eren Üniversitesi, Fen Edebiyat Fakültesi, Sosyoloji Bölümü/ Bitlis/ Türkiye E-Posta: celalince548@gmail.com

ORCID: 0000-0001-6081-4100

\section{Öz}

Uluslararası göç hem nedenleri açısından hem de sosyolojik ve politik sonuçları açısından dünya gündemini belirlemeye devam etmektedir. Bölgeler arasındaki ekonomik farklılıklar, yoksulluk, iç savaş, siyasal dönüşümler, ekolojik dengenin bozulması ve daha birçok faktör 21. yüzyılda birçok insanın göç etmesine neden olmuş ve gelecekte de bu olgunun dinamik kalacağı görünmektedir. Diğer taraftan uluslararası göçler hem göç veren hem de göç alan ülkeleri derinden etkilemektedir. Bununla birlikte göç ekonomi, politika, sosyal ve kültürel olmak üzere birçok alanı dönüştürmektedir. Dahası özellikle zorunlu göç sürecinde en çok yerinden edinmiş kişilerin kendisi etkilenmektedir. Bu bağlamda uluslararası göç birçok açıdan farklı disiplinler tarafindan incelenmesi gereken temel bir olgu olarak ön plana çımaktadır. Özellikle yakın dönemde iç çatışmalar sonucu Suriye'den diğer ülkelere gerçekleşen kitlesel göçlerin nedenleri, göç süreci ve meydana getirdiği sosyolojik sonuçları bütün boyutlarıyla araştırılmayı teşvik etmektedir. Bu çalışmada Suriye göçünün göç süreci göç kuramları açısından analiz edilmeye çalışılmaktadır.

Anahtar Kelimeler: Göç, Uluslararası Göç, Göç Teorileri, Göçmenler, Suriye.

\footnotetext{
${ }^{1}$ Bu çalışmanın önemli bir kısmı "Göçmenliğin Mekânsal Sosyolojisi: Şanlıurfa Örneği" başılılı doktora tezinden alıntıdır ve Suriyeli göçmenlerle ilgili yapılan değerlendirmeler, bu çalışmanın saha araştırması sürecinde yapılan mülakat ve gözlemlere dayanmaktadır.
} 


\title{
An Evaluation On Migration Theories and Syrian Migration
}

\begin{abstract}
International migration continues to set the world agenda in terms of both its causes and the outcomes of its sociological and political aspects. Economic differences between the regions, poverty, civil war, political transformations, deterioration of ecological balance and many other factors caused the migration of many people in the 21st century and this phenomenon seems to remain dynamic in the future. On the other hand, international immigration deeply affects both immigrant and emigrant countries. In addition, migration has many effects on the economics, politics, social and cultural areas. Moreover, the most effect occurred on displaced persons during the forced migration process. In this context, international migration comes to the forefront as a basic fact that need to research by the different disciplines. In particular, the reasons for the mass migrations from Syria to other countries as a result of the internal conflicts in recent times encourage the comprehensive investigation of the migration process and the sociological consequences. In this study, migration process of Syrian migration is tried to be analyzed in terms of the migration theories.
\end{abstract}

Keywords: Migration, International Migration, Migration Theories, Migrants, Syria. 


\section{Giriş}

Uzun tarihsel bir geçmişi olan göç olgusu; 19. yüzyıldan itibaren sistematik olarak incelenmeye başlanmış ve şimdiye kadar bu olguyu açıklamak üzere birçok kuram geliştirilmiştir. Geliştirilen kuramlar aynı olguyu açıklamasına rağmen birbirinden oldukça farklı hipotez, kavram ve önermelere sahiptir. Başka bir ifade ile tutarlı, tek bir uluslararası göç kuramından söz etmek mümkün değildir. Göç kuramlarının sahip olduğu parçalı yapının varlığı esasında çağdaş göç süreçlerinin tek bir kuram ya da disiplinle açıklanamayacağını göstermektedir. Dahası göç süreçlerinin karmaşık yapısı karma bir analiz biçimini gerekli kılmaktadır (AbadanUnat, 2002, s.4; Massey vd., 1993, s.432-3). Çünkü “günümüz toplumlarında ortaya çıkan her bir toplumsal olay ve olgu içinde çok parçalı ve kırıklı yapılar barındırmaktadır. Bir yandan 'büyük', kitlesel nitelikli olgu ve olaylarla karşılaşırken diğer yandan bu olay ve olgularının kendi içinde parçalandığını, kristalize olduğunu görmekteyiz. Çağımızda ortaya çıkan göçler ve genel olarak göç olgusu da bundan muaf değildir" (Çağlayan, 2006, s. 67). Ayrıca her dönemin sahip olduğu ekonomik, siyasi ve kültürel koşulları ve konjonktürel durum göç biçimi ve yönü üzerinde belirleyici olduğu gibi göç kuramları ve açıklamaları üzerinde de etkili olmaktadır.

Elma ve Şahin'e (2015, s.431) göre "nedenleri ve açığa çıkardığı sonuçları bakımından göç; ekonomik, kültürel, sosyal, politik ve güvenlik etmenleri bakımından çok boyutlu bir olgu olarak karşımıza çıkmaktadır." Bu bağlamda göçler arasında birtakım ortak özellikler bulunsa da toplumsal zeminde meydana gelen değişim ve dönüşüm her göçün kendine özgü özellikler barındırmasına yol açmaktadır. Bu toplumsal dönüşümler, yeni göç kuramlarının geliştirilmesinde temel rol oynamaktadır. Ayrıca Yalçın'a (2004) göre, her disiplin göç olgusunu ilgi alanına giren boyutuyla incelenmekte, ilgi alanına girmeyen kısımları üzerinde yoğunlaşmamaktadır. Örneğin; iktisat bilimi göçün ekonomik sebep, sonuç ve etkilerini araştırırken siyaset bilimi ise göçün politik yönlerini ve dış politika üzerinde oluşturduğu etkileri analiz etmektedir. Buna benzer; sosyoloji bilimi de sosyal ilişkiler boyutunu, sosyal ağların göç üzerindeki rolünü, göçün ekonomik, sosyal ve kültürel boyunu ele alarak göç olgusunu daha kapsamlı bir biçimde ele almaya çalışmaktadır. Ayrıca beşeri coğrafya göçü 
bir mekânsal değişiklik olarak tanımlarken, nüfus bilimi göçü nüfus hareketi, iktisat bilimi göçü işgücü hareketi olarak tanımlamaktadır (Somuncu, 2006, s.1-2).

Uluslararası göç konusunu genel olarak liberalizm, realizm, nominalist; Marksist bakış açısı, determinist, kapitali yükseltme yaklaşımı, hümanist yaklaşım, mikro, mezo, makro değerlendirmeler açısından ele almak mümkündür. Liberalizm açısından konuya bakıldığında, liberalizmin uluslararası göç, mülteciler, yerinden edilmiş kişiler veya vatansızlar üzerine doğrudan geliştirdiği bir yaklaşım bulunmamaktadır. Ancak olaylar geliştikçe geliştirdiği mekanizmalar vardır (Çelebi, 2011). Nominalist yaklaşım ise sığınmacıları ve diğer göçmenleri; devletlerin kısıtlayıcı göç politikası, iç piyasa ve ırkçılık gibi faktörlere dayanarak bir analiz yapar (Çelebi, 2011; Black, 1991). Marksist bakış açısı, göç olgusunu kapitalist sistemin yapısal bir sonucu olduğuna vurgu yapar (Çam, 2014, s.201; Bal vd., 2012, s.194). Bu bakış açısına göre uluslararası göç çözümlemesi, kapitalizmin dünya ölçeğinde yeniden yapılanması ile birlikte emek ve sermaye arasındaki ilişkinin açıklanması ile mümkün olabilecektir. Sınıflaşma, dünya ölçeğinde bölüşüm ve yeniden yapılanma bu sürece dâhil edilmediğinde çözümleme eksik kalacaktır. Bu bağlamda küresel krizler ve yoksullaşma süreci nüfus hareketliliği tetikleyen unsur olmaktadır (Erbaş, 2002).

Uluslararası göç mikro, mezo ve makro düzeyde de analiz edilebilmektedir. Mikro analize göre, insanlar göç ederken akrabalarının yanına ya da bilindik bir yere göç eder. Mezo analize göre, göç edenler bulunduğu ülkenin koşulları ile göç edecek ülkenin koşullarını karşılaştırır ve ona göre kararını verir. Makro analize göre ise, göç olayı nüfusun fazla olduğu istihdamın az olduğu durumlarda gerçekleşir. Determinist yaklaşımlar, göçmenlerin özelliklerine odaklanırken kapitali yükseltme yaklaşımı ücreti merkeze alarak bir analiz yapar. Hümanist yaklaşım ise göç etme konusunda bireyin verdiği kararı analiz eder (Parnwell, 2006; Faist, 2000).

Birçok toplumsal araştırma ve analizde olduğu gibi göç ve göçmen olgusu da analiz edilirken temel amaçlardan biri bu konuda geliştirilecek politikalara katkı sunmak ve bu alanda meydana gelen sorunların minimize edilme çabasıdır. Bu bağlamda göç kuramları açısından Suriye göçü analiz edilirken iki aşama üzerinde durulabilir. Bu aşamalardan biri Suriye göçünün sebepleri, failleri, diğeri ise göç süreci ve göçün sosyolojik 
sonuçlarının incelenmesidir. Erbaş'a (2018) göre göç bir sebep değil bir sonuçtur ve bu sonucun sebepleri, aktörleri ve yapısal süreç incelenmeden göç sorunu hakkında gerçekçi çözümler üretmek oldukça zordur. Bu bağlamda gerçekçi politikaların geliştirilmesi açısından göçün dinamiklerini analiz etmek en az göçün sonuçları analiz etmek kadar önemli ve gerekli olduğu düşünülmektedir. Bu bağlamda göç edenlerin sığınmacı duruma gelmesinde belirleyici koşullara odaklanan realist yaklaşım Suriye göçü için önemli bir bakış açısı sunmaktadır. Devletlerin çıkar ve güç tercihini ön planda tutan bu pragmatist bakış açısı Suriye' de çatışmaların bir türlü bitmemesinin esas omurgasını oluşturmaktadır. Küresel aktörlerin Suriye üzerindeki realist yaklaşımı sadece çatışma ve çatışmaya bağlı göçün devamını sağlamamakta aynı zamanda göçmenlerin gelişini engelleme çabası da Suriyeli göçmenleri bir sömürü alanına dönüştürmesine neden olmaktadır (Babahanoğu ve Bilici, 2018). Bu açıdan Suriye'deki çatışmaların beslendiği kaynaklardan birini iç dinamikler oluştursa da esas olarak realist perspektife göre hareket eden küresel aktörler süreç üzerinde belirleyici olmaktadır. Başka bir ifade ile özellikle kitlesel zorunlu göçmenlerin kaynağını çatışma, çatışmanın esas kaynağını ise insan merkezli yerine ç1kar merkezli küresel aktörlerin uluslararası politikaları oluşturmaktadır. Diğer göç kuramları ve bu kuramların Suriye göçünü açılama potansiyeli aşağıdaki alt başlıklarda değerlendirilmektedir.

\section{Ernst Georg Ravenstein Kuramı}

Göç olgusunu açıklamaya çalışan ilk kuramlardan biri Georg Ravenstein'nin 1885 ve 1889 tarihlerindeki “The Laws of Migration” adlı çalışmalarıdır. Ravenstein' in göçle ilgili temel düşünceleri bu çalışmalarda belirttiği gibi şu temel varsayımlara dayanmaktadır:

1. Göçmenlerin önemli bir kısmı kısa mesafelere göç eder. Bu göç sarsıcı bir etki oluşturarak, yerel halkı da yerinden etmekte, daha büyük ve kitlesel göçlere yol açmaktadır. Bu göç akımları genellikle sanayi ve ticaret merkezlerine doğru gerçekleşmektedir. Bu bağlamda sanayi ve ticaret merkezlerinin gelişmişlik düzeyi etrafındaki nüfus yoğunluğu üzerinde belirleyici olmaktadır. 
2. Sanayi ve ticaretin gelişmesine paralel olarak kentler, çeperdeki ve yakın mesafedeki insanlar için bir cazibe merkezi haline gelmektedir. Yakın çevreden kente göç eden insanların yerini oraya yakın başka insanlar tarafından doldurulmaktadır. Bu bağlamda yakın mesafe ile başlayan göç bir domino taşı görevini görerek göçün bütün dünyaya yayılmasına neden olmaktadır.

3. Göçün yayılma ve emme süreci benzer özelliklere sahiptir. Sanayi ve ticaretin geliştiği kentlerden faydalanmak üzere insanlar bu merkezlere doğru yayılırken sanayinin gelişmesine paralel olarak meydana gelen işgücü ihtiyacı çevreden göçmen emilerek giderilir. Başka bir ifade ile göçmen alan merkez ile göçmenler arasında bir arz talep dengesi söz konusudur.

4. Bir göçün başlaması diğer bir göç akımının gerçekleşmesini tetikleyerek zincirleme göçü meydana getirir.

5. Bir başka göç türü de kısa mesafe yerine sanayi ve ticaret merkezlerinin bulunduğu uzun mesafelere doğrudan yapılan göçlerdir.

6. Kırda yaşayan insanlar kentte yaşayan insanlara göre daha çok göç etme eğilimi taşırlar. Ayrıca kırdan kıra yapılan göçler birbirini tetikleyerek başka göçlere yol açarken kırdan kente yapılan göçlerde bu olgu daha azdır.

7. İç göçlerde ve kısa mesafeli göçlerde kadınlar erkeklere göre daha fazla göç eğilimi taşırken uzun mesafeli göçlerde durum tam tersidir (Ravenstein, 1885, s.198-9; Ravenstein, 1889).

Ravenstein'in göçle ilgili ortaya koymuş olduğu ilk beş kanunu esas olarak iki temel modele dayanmaktadır. Bunlardan birincisi; göç kısa mesafeli yerlere, gelişmiş sanayi ve ticaret merkezlerine doğru yapılır, basamaklı bir biçimde zincirlemeli olarak gerçekleşir. İkinci göç modeli doğrudan uzun mesafeli, gelişmiş sanayi ve ticaret merkezlerine doğru yapılır (Çağlayan, 2006, s.70). Sonuç olarak Ravenstein, uluslararası göçün nedenleri arasında coğrafik ve siyasi nedenleri saysa da esas olarak ekonomik koşulları merkeze almıştır. Ona göre, bireyin göç etmesinin temel nedeni bireyin ekonomik durumunu iyileştirme çabasından gelmektedir. Sanayi ve ticaret geliştikçe bu göç devam edecektir (Yalçın, 2004, s.26). Ravenstein'in göçle ilgili açıklamaları ekonomik nedenlere odaklansa da Suriye göçünün açıklanmasına da önemli bir katkı sunmaktadır. 
Ravenstein'in vurguladığı mesafe bütün göçmenler için önemli olmasa da dünyadaki zorunlu göçmenler için hayati önem taşımaktadır. Ülkelerindeki çatışma ve baskılardan dolayı Afganistan, Güney Sudan, Myanmar ve Somali'den göç etmek zorunda kalanların büyük çoğunluğu komşu ülkelere göç etti. Afganistan'dan göç etmek zorunda kalanlar komşu ülkeler Pakistan ve İran'a; Güney Sudan'dan göç edenler Kenya, Sudan, Etiyopya ve Uganda'ya; Myanmar'dan göç edenler Bangladeş'e; Somali'den göç edenlerin çoğu da Kenya'ya sığınmış durumda. Suriye'deki çatışmalardan dolayı göç etmek zorunda kalanlar da tıpkı sözü edilen ülkelerde olduğu gibi çoğunluğu Türkiye olmak üzere komşu ülkelere göç etti. Bu bağlamda özellikle zorunlu kitlesel göç süreçlerinde hedef ülkenin belirlenmesinde hedef ülkelerin göç politikaları ve kültürel yapıları ile birlikte fiziksel mesafe önemli bir bileşen olarak yer almaktadır. Çünkü Suriye göçünde olduğu gibi iç çatışmalara bağlı dünya üzerindeki kitlesel zorunlu göçmenlerin çoğu uzun mesafeye göç edecek ekonomik ve sosyal sermayeye sahip değiller. Göçmenlerin gitmek istediği refah düzeyi yüksek Batı Avrupa ülkelerinin göçü bir güvenlik problemi haline getirerek Suriyeli göçmenleri engelleme çabası, hatta pazarlık konusu haline getirmesi ve fiziksel mesafenin fazla olması Suriyeli göçmenlerin yakın bölgelere göç etmesinde belirleyici etken olmuştur. Göç ile ilgili belirtilmesi gereken diğer bir husus Ravenstein'ın da belirttiği üzere göçmenlerin sanayi ve ticaret merkezlerine yönelmesidir. Suriye göçünün ilk sürecinde fiziksel mesafe Türkiye'deki Suriyeli göçmenler için önemli bir unsur olsa da zamanın uzamasıyla birlikte yaşamlarının devam edilmesindeki diğer unsurlar önemli hale gelmektedir. Bu bağlamda Suriye sınırına yoğunlaşan Türkiye'deki Suriyeli göçmenlerin sonraki hedefleri İstanbul, Bursa, İzmir ve Konya gibi büyük kentler olmuş ve sınır bölgelerden bu kentlere doğru göç devam etmektedir. Örneğin göçün ilk sürecinde bu kentlerde neredeyse hiç Suriyeli göçmen bulunmazken Göç İdaresi Genel Müdürlüğü verilerine göre; 02.05.2019 tarihi itibari ile İstanbul'da 546.384, Bursa'da 169.621, İzmir'de 142.513 ve Konya'da 106.345 Suriyeli göçmen ikamet etmektedir. ${ }^{2}$

${ }^{2}$ http://wwww.goc.gov.tr/icerik3/gecici-koruma_363_378_4713, Erişim tarihi:07.05.2019. 


\section{İtme Çekme Kuramı}

İnsanlık tarihi boyunca göç olgusu hep var olmuş ve günümüzde de devam etmektedir. Günümüz göçlerin birçok farklı dinamiği bulunmakla birlikte daha çok birbiriyle de ilişkili olan iki değişkenin bu süreçte belirleyici rol oynadığı görülmektedir. Bunlardan birisi bölgelerarası refah düzeyi farklılığı, yoksulluk ve diğer ekonomik bileşenler diğeri ise çatışmalı durumun birçok bölgeyi etkisi altına alınmasıdır. Bu durumu Lee, itmeçekme teorisiyle açıklamıştır. Lee, $A$ Theory of Migration adlı makalesinde göçün meydana gelmesinde etkili olan faktörleri itme ve çekme başlığı adı altında sınıflandırmıştır. Bu çerçevede ona göre kararın verilmesinde ve göç sürecinde etkili olan faktörler dört başlık altında sinıflanabilir:

1. Menşe ülke ile ilgili faktörler

2. Hedef ülke ile ilgili faktörler

3. Araya giren engeller

4. Bireysel faktörler (Lee, 1966, s.50)

Lee'ye göre bir nüfus hareketinin meydana gelebilmesi için menşe ülke ve hedef ülkeyle ilgili aşağıdaki tabloda gösterildiği gibi sayısız itici ve çekici faktör bulunmaktadır. İtici ve çekici faktörler hem menşe ülkede hem de hedef ülkede bir aradadır.

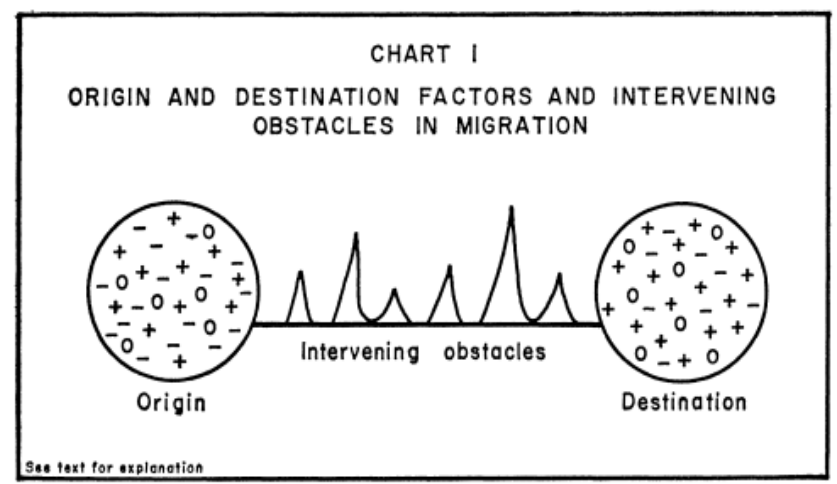

Şekil 1: Köken ve Varış Faktörleri ile Göç Etmede Araya Giren Engeller (Lee, 1966, s. 50)

Şekildeki (+) işaretler çekici, (-) işaretler itici ve (o) işareti ise nötr faktörler anlamına gelmektedir. Ancak hangi unsurların göç eden bireyler 
için itici faktör olduğu ve hangi unsurların çekici faktör olduğu net değildir. Başka bir ifade ile itici ve çekici faktörler kişiden kişiye göre değişebilmektedir. Bireyin yaşı, cinsiyeti, eğitim düzeyi ve aidiyeti gibi özellikler bu konuda belirleyici olmaktadır. Ayrıca göç sürecinin sosyal bağlamı da bu konuda etkili olmaktadır. Eğitim çağındaki çocukları olan bir aile için gidilecek yer eğitim açısından aileye itici ve çekici faktörler oluştururken çocukları olmayan biri için eğitim ile ilgili faktörler nötr özelliktedir. Bu çerçevede itici ve çekici faktörler farklı konumda bulunanlar için iyi tespit edilmesi gerekir (Çağlayan, 2006, s.73). İtme çekme kuramı, insanların ülkelerinden ayrılmasına yol açan faktörler ile yeni bir ülkeye gitmelerini etkili kılan faktörleri analiz etmektedir (IOM, 2009, s.30).

İtme çekme kuramına benzer bir biçimde göç olgusunu açklayan başka bir kuram kesişen fırsatlar kuramıdır. Bu kurama göre, göç süreci üzerinde belirleyici olan temel faktörler; göç mesafesi, hedef ülkedeki imkânlar ve bu imkânların düzeyidir. Bu unsurların kesişimi göçün yoğunluğu üzerinde etkili olmaktadır. Bu kuram açısından göç mesafesi oldukça önemli bir unsurdur. Çünkü özellikle uluslararası göç hareketlerinde kaynak ve hedef ülke arasındaki mesafe uzadıkça göçmenin aşması gereken sınırlar ve engeller çoğalmaktadır. Dolayısıyla her sınırda ayrı mekanizma ve hukuki süreçler işlendiğinde göçmenin hedef ülkeye ulaşma ihtimali azalmaktadır. Bununla birlikte göçmenin göç ettiği yerdeki fırsatların çokluğu, iş imkânlarının bolluğu gibi unsurlar göç hacminin genişlemesine neden olmaktadır. Kesişen fırsatlar kuramına göre potansiyel göçmen kâr ve zararı hesapladıktan sonra göç etme(me)ye karar vermektedir (Kapu, 2012, s.15).

İtme çekme kuramı ve kesişen fırsatlar kuramı uluslararası göç analizinde genel bir bakış açısı sunmakla birlikte bu kuramlar açısından hangi unsurlardan dolayı Suriye göçünün gerçekleştiği ve göç edilecek bölgenin seçilmesinde hangi unsurların daha belirleyici olduğu konusunda bir analiz yapmanın faydalı olacağ 1 düşünülmektedir. Menşe ülke olarak Suriye göçünün çatışmaya bağlı meydana geldiği konusunda genel bir kanı bulunsa ve başat neden bu olsa da bütün Suriyelilerin bu nedenden dolayı göç ettiğini söylemek mümkün değildir (İnce, 2018). Dahası hem dönemsel olarak hem de mekânsal olarak Suriye göçü birçok farklılı̆̆ı barındırmaktadır. Suriye göçünün başladığı ilk dönemlerde, göç eden kişilerle ya- 
pılan günlük konuşmalarda çatışmanın olmadığı bölgelerden bile ekonomik sermayesi yüksek, Suriye'ye aidiyet düzeyleri düşük bireylerin de Türkiye'ye göç ettiği görülmüştür. Benzer bir biçimde daha sonraki dönemlerde de çatışmanın olmadığı bölgelerden askerlik çağındaki kişilerin göç ettiği bilinmektedir. Dolayısıyla çatışmalarla birlikte, aidiyet düzeyinin düşük olması, alt yapının tahrip olması, işsizlik, yoksulluk ve askere alınma gibi bir dizi itici faktörün Suriye göçünün artışında belirleyici olduğu bilinmektedir.

Sonuç olarak AFAD'ın hazırlamış olduğu rapora (2014) göre, Suriye göçünün en önemli itici faktörü güvenlik ya da siyasi nedenler ve göç etmenin en önemli çekici faktörleri arasında güvenli bir bölgeye ulaşma hedefi olsa da Şahin'nin (2015) yapmış olduğu çalışmada belirttiği gibi iş imkânı, Suriyeli göçmenlere yönelik takip edilen politika ve ulaşım kolaylığ1 gibi unsurlar da Suriyeli göçmenlerin Türkiye'ye göç edilmesinde önemli çekici faktörler arasında yer almaktadır. Özellikle sınır bölgesi açısından bakıldığında göçmenler ile yerel toplum arasındaki dil birliği ve benzerliği (Arapça, Kürtçe, Türkçe) (Çağlayan, 2015), sınırın iki yakası arasındaki tarihsel sosyal ilişkilerin varlığı çekici faktörlerin ve fırsatların diğer unsurlarını oluşturmaktadır (Kaya, 2017). Suriyeli göçmenlerin Türkiye'ye yoğunlaşmasında özellikle açık kapı politikasının belirleyici olduğu gibi Türkiye'ye göç eden her bir Suriyeli göçmenin Türkiye'de kalmasında ya da bir Batı Avrupa ülkesine göç etmesinde bireysel faktörler bağlamında sahip olunan sermaye biçimleri de rol oynamaktadır (İnce, 2018). Başka bir ifade ile çekici faktörler hedef bölgenin özelliklerini içermekle birlikte bireyin sahip olduğu ekonomik ve sosyal sermaye ile kültürel yetkinlikle de ilgilidir.

\section{Neoklasik Ekonominin Makro Kuramı}

Uluslararası göç hareketlerini açıklamak üzere geliştirilen kuramlar ilk başlarda temel olarak ekonomiyle ilintili bir biçimde kurgulanmıştır. $\mathrm{Bu}$ bağlamda söz konusu bu kuramın dayandığı temel varsayım, iç göç ve uluslararası göç emek konusundaki arz ve talep dengesinde meydana gelen coğrafik farklılıktan kaynaklanmaktadır. Bu göç kuramına göre, emek fazlasına sahip olan ülkeler ücret açısından düşük bir piyasaya sahipken 
sermayenin fazla olduğu ülkelerde sermayeye kıyasla ücretler yüksek olmaktadır. Bu bağlamda kişiler emek ücretinin az olduğu ülkeden emek ücretinin fazla olduğu ülkeye göç etmektedir. Bu nüfus hareketinin bir sonucu olarak emek fazlalığı olan ülkelerde emek piyasası daralırken emek piyasası açısından yoksun olan ülkelerde emek zenginleşmektedir. Dolayısıyla ülkeler arasındaki nüfus hareketleri aracılığıyla ücretlerde ve emek piyasasında ülkeler arasında bir denge oluşmaya başlamaktadır (Robinson, 2005, s.5; Abadan-Unat, 2002, s.6; Massey, 1999, s.35).

Bu kurama göre, uluslararası göçün esas nedeni, ülkeler arasındaki ücret ve istihdam koşulları arasındaki farktan kaynaklanmaktadır. İşçi olarak çalışan insanlar, ücretin az olduğu ülkeden ücretin yüksek olduğu ülkeye göç ederler. Ülkeler arasındaki ücret farklılığı ne kadar fazla ise insan hareketliliği de buna paralel olarak yoğun yaşanır. Bu nüfus hareketliliği sonucunda sermaye zengini olan ülkelerde ters orantılı olarak emek arzı artarken ücretler gittikçe düşer, sermaye açısından yoksun olan ülkelerde durum tam tersi gelişir. Benzer bir biçimde ülkelerarasında sermaye akışı da gerçekleşir. Sermaye yoksunu ülkelerde sermaye yatırımının getirisi fazla olduğundan sermaye açısından zengin olan ülkelerden sermaye açısından yoksun ülkelere doğru sermaye akışı gerçekleşir. Bu sermaye akışı sadece fiziki sermaye ile sınırlı değildir, beşeri sermayeyi de kapsar. Bu kurama göre, nitelikli işçi sayısının az olduğu ülkelerde nitelikli emeğin karşllığ1 yüksek olur. Bu kapsamda nitelikli işçi sayısının fazla olduğu ülkelerden nitelikli işçi sayısının kıt olduğu ülkelere akış gerçekleşir (Massey vd., 1993, s. 433). Abadan-Unat, Massey ve Massey vd. bu kuramin temel varsayımlarını şu şekilde özetlemektedir:

1. Ülkeler arasındaki işgücü ücret farklılığı uluslararası göçün temel nedenini oluşturmaktadır.

2. Bu bağlamda ücret farklılığının olmadığı yerde, nüfus hareketliliği de olmayacaktır.

3. Ülkeler arasında nitelikli işgücünün getirisi ile niteliksiz işgücünün getirisi arasında farklar olabilir. Başka bir ifade ile sermaye açısından kıt olan ülkelerde sermayenin oraya akması ile nitelikli işgücünün getirisi diğer ülkelerden yüksek olabilir. Böylece nitelikli ve niteliksiz işgücü hareketliliğinin yönü arasında fark vardır.

4. Uluslararası göç üzerinden belirleyici olan temel dinamik işgücü piyasalarıdır. 
5. Hükümetler insan hareketliliğini kontrol altına almak istiyorlarsa ülkelerarasındaki işgücü piyasası üzerinde belirleyici ve yönlendirici olması gerekir (Abadan-Unat, 2002, s.6-7; Massey, 1999, s.35; Massey vd., 1993, s.434).

Bu kuram, uluslararası nüfus hareketlerini esas olarak ekonomi temelli açıkladığından daha çok çatışma nedenli Suriye göçünü açıklama potansiyeli çok fazla taşımadığı düşünülmektedir. Ancak çatışma, iş ve istihdam birbirinden bağımsız olgular değiller. İç çatışmaların olduğu bölgelerde istikrarlı ve yüksek ücretli bir iş imkânına sahip olmak oldukça zordur. Dahası savaş ve çatışma işsizlik ve yoksulluğu da beraberinde getirmektedir. Bu bağlamda çatışma nedeniyle göç eden birçok Suriyeli göçmenle birlikte işsizlik ve düşük ücretten dolayı Suriye'den göç eden birçok göçmen de bulunmaktadır. Nitekim Özkarslı'nın yapmış olduğu çalışmada, can güvenliği tehdit altında olduğundan dolayı göç eden Suriyeli göçmenin yanında ekonomik nedenlerden dolayı göç eden Suriyeli göçmen sayısının da fazla olduğu görülmektedir. Çatışmadan dolayı özellikle Türkiye'nin Suriye'ye sınır illerine göç eden Suriyeli göçmenlerin de neredeyse yarısı işsiz durumdadır (Özkarslı, 2014). Zamanla bu işsizlik oranı azalsa da çalışan göçmenlerin önemli bir kısmı ikincil sektörlerde iş bulabilmektedir. Sınır bölgesinde ikamet eden göçmenlerle ilgili yapılan bir araştırmada, göçmenlerin öncelikli sorunları arasında işsizlik ve yüksek kira olduğu görülmektedir (Kaynak, vd., 2016). Türkiye'nin Suriye sınırına yerleşen bu göçmenler zamanın uzaması ile birlikte daha rahat ve yüksek ücretli iş bulabileceği Türkiye'nin batı illerine ve Batı Avrupa ülkelerine göç etmeye çalışmaktadır. Başka bir ifade ile Suriye göçünün ilk aşamasında güvenlik önemli bir sorun iken daha donra hem Suriye'nin çatışma olmayan bölgelerinde hem de Suriye'den göç edenler için istihdam önemli bir sorun haline gelmeye başlamış bulunmaktadır. Küresel ve bölgesel iş birliğine dayalı bir çözüm hayata geçirilmediği taktirde yakın gelecekte de bu sorunların devam edeceği tahmin edilmektedir.

\section{Neoklasik Ekonominin Mikro Kuramı}

Bu kuram, özellikle gelişmiş ülkelerde entegrasyon ve göç politikasının şekillenmesi üzerinde etkili olmuştur. Bu kuram; neokilasik ekonominin makro kuramından farklı olarak, özellikle zengin ülkeler perspektifinden 
beşeri sermaye çerçevesinde bireyin rasyonel tercihini merkeze alarak uluslararası göç olgusunu açıklamaya çalışır. "Beşeri Sermaye Modeli" olarak uluslararası göçü; kar, zarar ve riskleri iyi hesaplanmış, bireysel aktörler tarafından karar verilmiş bir beşeri sermaye yatırım aracı olarak değerlendirir. Neoklasik ekonominin mikro kuramına göre; rasyonel aktörler olarak bireyler, beşeri sermayesini geliştirebileceği ve bu konuda yat1rım yapabileceği ülkeleri tercih ederler. Fakat buna karar vermeden önce beşeri sermayesinin kendi ülkesindeki değeri ile gideceği ülkenin değeri arasındaki farkı çok iyi hesaplar (Robinson, 2005, s.6). Bu bağlamda bireyler rasyonel tercihte bulunarak göç etme sonucunda kâr ve maliyeti k1yaslayarak daha yüksek kâr elde edebileceği durumda göç etmeye karar verir. Başka bir ifade ile göç süreci bireyin daha yüksek kâr elde etme planıyla başlamış olur. Böylece bireyler daha maksimum kâr elde edeceği coğrafik bölgelere göç etmeye karar verirler ve bunun için hazırlığını yapar. Bu hazırlık; yolculuk giderleri, dil öğrenme ve uyumu kolaylaştıracak süreçlerden oluşmaktadır. Bununla birlikte birey yasadışı yollarla göç etmeye karar vermişse hapis cezası, sınır dışı edilme ve ölüm tehlikesi gibi riskleri de hesaba katmaktadır (Abadan-Unat, 2002, s.7). Bu kuramın uluslararası göçle ilgili temel varsayımlarını Massey ve Massey vd., şu şekilde özetlemektedir:

1. Bu kurama göre uluslararası insan hareketliliği neoklasik ekonominin makro kuramın savunduğu tam istihdam yerine ülkelerarasındaki hem istihdam hem de kazanç arasındaki farktan kaynaklanmaktadır.

2. Göç eden kişinin eğitim düzeyi, tecrübesi ve farklı dillere hâkimiyeti gibi özelliklere bağlı beşeri sermayesi göç ettiği ülkede iş bulma olanağı üzerinde etkili olmaktadır.

3. Uluslararası göçün artışında göçün maliyetini düşüren getirisini artıran bireysel nitelikler, sosyal koşullar ve teknoloji belirleyici olmaktadır.

4. Uluslararası nüfus hareketleri; kar-zarar temelinde gerçekleşen bireysel geçlerin toplamından oluşmaktadır.

5. Ülkeler arasında kazanç ve istihdam oranları arasında bir fark yoksa göç hareketi meydana gelmez. 
6. Ülkeler arasındaki getiri farkı göçün boyutu üzerinde belirleyici olur. Getiri farkının büyümesine paralel olarak göçmen miktarında artış olur.

7. Göç kararı esas olarak işgücü piyasası arasındaki dengesizliklere göre şekillenir. Diğer pazarlar göç kararı üzerinde doğrudan belirleyici olmaz.

8. Göç alan ülkelerde göçmen alımına yönelik çekici koşullar varsa göçün kontrolü için göçün maliyeti yükseltilebilir.

9. Hükümetler, göç alan ülkelerde istihdam ve kazanç oranlarını sınırlandırarak, göç veren ülkelerde de bu şartları iyileştirerek insan hareketliliğini kontrol eder (Massey, 1999, s.35-36; Massey vd., 1993, s.435-436).

Bu kuram da bir önceki kuram gibi Suriye göçünü tam açıklamasa da anlaşılmasında bir parça katkı sunmaktadır. Suriyeli göçmenler homojen bir grup değil; eğitim, etnisite, mezhep, din, cinsiyet gibi birçok farklılığ barındırmaktadır (Çağlayan, 2015). Eğitim düzeyi düşük bireylerle birlikte yüksek beşeri sermayeye sahip bireyler de Suriye'den ilk etapta komşu ülkelere göç ettiler. Ancak beşeri sermaye açısından zengin bu kişiler göç ettiği komşu ülkelerde ya kendi vasfına uygun iş bulamadılar ya da çok ucuz çalışmak zorunda kaldılar. İlk süreçte Suriye'nin komşu ülkelerine sığınan bu kişilerin önemli bir kısmı kendi vasfına uygun daha kolay iş bulabileceği Batı ülkelerine göç ettiler ve göç etmeye devam etmektedir. Bu bağlamda Suriyeli göçmenin sahip olduğu beşeri sermayesi, tecrübesi ve farklı dillere hâkimiyeti, istihdam ve kazancı belirli bir üçüncü ülkeye göç etmesinde etkili olmaktadır. Nitekim Erdoğan'ın (2015) yapmış olduğu çalışmada, eğitimli ve vasıflı Suriyeli göçmenlerin Türkiye'de kendi vasıflarına uygun iş imkânının yaygın olmadığı ve bu yüzden Batı Avrupa ülkeleri, ABD ve Kanada gibi ülkelere gitmek istediklerini belirttikleri görülmektedir.

\section{"Yeni Ekonomi" Kuramları}

Yeni ekonomi kuramı, neo-klasik ekonomi kuramının bir eleştirisi üzerine geliştirilmiş bir model olarak düşünülebilir. Çünkü neo-klasik ekonomik kuram, referans birimi olarak bireyi merkeze almaktaydı. Oysa Stark ve Bloom'a (1985, s.174) göre; göç kararı sadece bireyler tarafından değil göç 
eden ve etmeyen olmak üzere birbiriyle ilgili insanlar tarafından kolektif bir biçimde alınmaktadır. Ayıca göçmenin geride kalan yakın akrabalaryyla gönderdiği dövizler başta olmak üzere birçok kanal üzerinden ilişkisi devam etmektedir. Başka bir ifade ile göç sadece bireyi ilgilendiren ve bireyin tek başına aldığı bir karar değil hane halkının davranış ve beklentileri de karar alma sürecinde etkili olmaktadır.

Bu kuram neo-klasik ekonomik kuramclların öne sürdüğü gibi göçü, sadece kârın maksimize edilmesi amacı taşıyan bir olgu olarak değerlendirmemektedir. Bireyin ayrıldığı ülkenin koşulları da bu süreçte belirleyici olmaktadır. Bu çerçevede düşünüldüğünde gelişmiş ülkelerin önemli bir kısmında hane gelirlerine yönelik riskler sistemleşmiş bazı mekânizmalarla azaltılmaya çalışılmaktadır. Bu bağlamda az gelişmiş toplumlarda ailenin gelir kaynaklarını etkili bir biçimde kullanmak açısından ailenin ortak kararı bireyin tercihlerinden daha önemlidir. Özellikle ekonomik bunalımlar döneminde aile fertleri önemli stratejiler geliştirir. Ailenin bazı fertleri yerel işlerde çalışırken, bir kısmı ülkenin farklı bir coğrafyasında çalışır. Ailenin bir kısmı ise başka ülkelerde çalışarak ekonomik bunalım dönemlerinde ailenin diğer fertlerine yardım eder. Böylece gelirin miktarında bir artış olmasa bile gelirin kaynağında bir çeşitliliğe gidilmiş olması yerel piyasaların riskli dönemlerinde aileye önemli bir teminat sağlamaktadır (Abadan-Unat, 2002, s.8; Stark ve Bloom, 1985, s.174-5) . Massey ve arkadaşları, bu kuramın temel varsayımlarını şu şekilde sıralamaktadir:

1. Göç araştırmalarının analiz merkezini salt birey yerine kolektif birimler, aileler, hane halkı ve diğer üretim, tüketim birimleri oluşturur.

2. Uluslararası insan hareketliliği, sadece ülkeler arasındaki ücret farklılığından kaynaklanmıyor. Örneğin bu farkın olmadığı durumlarda bile aileler yerel piyasanın risklerini minimize etmek için kaynak çeşitliliğine gidebilir ve bu kapsamda ailelerin bazı fertleri farklı yerlere gönderilebilir.

3. Yerel istihdam ve üretim ile uluslararası göç arasında doğru bir ilişki yoktur. Hatta yerel piyasaya dâhil olma ile göç arasında bir paralellik olabilir. Hane halkı yerel, piyasadan elde ettiği gelirleri 
daha büyük bir yatırım aracına dönüştürmek için yurt dışına göçmen vererek kaynak çeşitliliğine gidebilir. Daha çok yatırım için böylece sermaye ve risk kısıtlamasını ortadan kaldırabilir.

4. Uluslararası göçün durulması için ülkeler arsındaki ücret farklıl1ğın eşitlenmesi yeterli bir ölçü değildir. Diğer piyasaların varlık ya da dengesizlik durumu da göçü etkiler.

5. Farklı konumlarda bulunan hane halklarının eşit kazanç beklentisi ile göç etme olasılığı arasında düzenli bir ilişki yoktur.

6. Hükümetlerin işgücü piyasasının kontrolü göçün kontrol edilmesi için yeterli bir unsur değildir. Hükümetler; işsizlik sigortası gibi sigorta piyasalarla, sermaye ve vadeli piyasalarla göçü etkileyebilir ve şekillendirebilir. Özellikle işsizlik sigortasının varlığı, göçmenler için çekici bir unsur oluşturur.

7. Hükümetlerin hane halklarının gelir dağılımını belirleyen politikaları hane halkının yoksulluk düzeyi üzerinde etkili olur. Hane halkı gelir durumu da göç etme arzusu üzerinde belirleyici olur.

8. Hükümetlerin hane halkı gelir dağılımını etkileyen politikaları ve ekonomik yenilikler, hane halkının göç etme isteği üzerinde farklı etkiler oluşturur. Örneğin ekonomik teşviklerden göreli yoksul hane halkı yararlanmıyorsa göç oranında artış olabilir, eğer zengin hane halkı yararlanmıyorsa göç oranında azalma olabilir (Massey vd., 1993, s.439-40).

Neoklasik ekonomi kuramı gibi yeni ekonomi kuramı da Suriye göçünün anlaşılmasını kolaylaştırmaktadır. İşsizlik daha önce de ifade edildiği gibi yıllardır çatışmaların hâkim olduğu hem Suriye' de hem de komşu ülkelere sığınan Suriye göçmenler için önemli bir sorun olarak yer almaktadır. İş bulanlar da istikrarlı bir iş bulmakta zorlanmaktadır. Bu sorunu çözmek için bütün aile fertleri göç etmek yerine bazı ailelerin daha kolay iş bulabileceği fertleri göç etmektedir. Bu kişilerin geride kalan aile fertlerine göndermiş olduğu yardımlarla aileler geçimlerini sürdürmeye devam etmektedir. Bu durum üçüncü ülkeye göç etmek isteyen Suriye'ye komşu ülkelerdeki Suriyeli aileler için de geçerlidir. Komşu ülkelerdeki Suriyeli göçmenler hem benzer bir kültür ve dile sahip olduğu için hem de Batı ülkeleri her özellikteki Suriyeli göçmeni almak istemediğinden do- 
layı beşeri sermayesi yüksek aile fertleri bir Batı Avrupa ülkesine göç etmekte ve gönderdiği yardımlarla geride kalan aile fertleri hayatını devam ettirmektedir.

\section{İkiye Bölünmüş (segmented) Emek Piyasası Kuramı}

Abadan-Unat'a göre, neoklasik ve yeni göç ekonomisi kuramlarının geliştirmiş olduğu varsayım ve önermeler uluslararası göç açısından birbirinden farklılaşsa da her ikisi de mikro bir perspektif sağlamaktadır. İki kuram arasındaki temel fark ise göç kararının kim tarafından verildiği, gelirin nasıl hesaplandığı, göç kararının toplumsal değerlendirmesi gibi konulara yoğunlaşmaktadır. Ancak ikiye bölünmüş emek piyasası modeli farklı bir bakış açısı sunmaktadır. Bu kuram esas olarak uluslararası göç hareketini modern sanayi toplumları açısından değerlendirmekte ve göçün sanayi toplumunun işgücü piyasasının talebinden kaynaklandığını iddia etmektedir (Abadan-Unat, 2002, s.10-1).

Bu kuramın öncülerinden olan Piore'ye (1979) göre uluslararası göç, göçmenlerin anavatanındaki faktörlere bağlı olarak gelişmemekte tam tersi hedef ülkenin emek ihtiyacına bir cevap olarak ortaya çıkmaktadır. Bu kurama göre göç, ikili işgücü piyasası hipotezine dayanılarak açıklanmaktadır. Hiyerarşik olarak belirlenen birinci işgücü piyasasında genellikle yerel halk ikinci işgücü piyasasında ise göçmenler çalışmaktadır. Bunu besleyen bazı faktörler vardır. Bu faktörlerden biri; ücret yapısı ve yapısal enflasyondur. Mesleki statü ve ücret arasında bir ilişki vardır ve toplumda böyle bir algı oluşur. Dolayısıyla yerel halkın büyük çoğunluğu hem toplumsal statü olarak hem de ücret olarak birincil sektörde çalışmak ister. İşverenler, ikincil sektörü daha cazip kılmak için ücretleri yükselttiğinde mesleki statü ve ücret ilişkisine bağlı olarak birincil sektördeki ücretleri dolaylı olarak yükseltmesi gerekir. İşverenler çözümü, ikincil sektördeki mesleklerde yerel halka göre daha çok riza gösteren ve düşük ücreti kabul eden göçmenleri istihdam etmekle bulur. İkili iş piyasasının ikincil sektörünün göçmenlere devredilmesini besleyen başka bir faktör, motive edici bir göç olarak mesleki hiyerarşidir. İnsanlar, sadece ücret almak için değil mesleki statü olarak yükselmek için de çalışır. Ancak ikincil sektörde çalışanlar için bu pek mümkün görünmüyor. Çünkü toplumsal statü olarak en alt meslekten üst mesleklere doğru hareketlilik oldukça 
azdır. Motivasyonsuzluğa neden olan bu durum yerel halkın bu mesleklere yönelmesi engellemektedir. Göçmenler ise temel ihtiyaçlarını karşılamak için bu mesleklerde çalışmayı kabul eder. Hatta göçmenler aldığı ücreti kendi ülkelerindekiyle karşılaştırdığında, ücretler onlar için yüksek gelebilir. İkili işgücü piyasasını besleyen diğer bir faktör piyasanın sahip olduğu düalizmdir. Sermaye, üretimin sabit faktörlerinden iken işgücü değişken bir faktördür. Birincil iş piyasasında çalışan bireylerin oldukça iyi bir beşeri sermayeye sahip olması gerekir ve sermaye sahipleri beşeri sermayelerini geliştirmek için sürekli yatırım yapar. Dolayısıyla bu sektördeki kişilerin işten çıkması aynı zamanda sermaye kaybı anlamına gelir. İkincil sektörde çalışan genellikle vasıfsız kişilerdir. Vasıfsız kişileri memnun etmek daha kolaydır. Hatta başkasıyla değiştirilebilir. Çünkü yedekte bekleyen bir işçi ordusu mevcuttur. Ancak birincil sektördeki kişiler için durum böyle değildir. Bu bağlamda yerel kişiler, işin daha istikrarlı, sağlam ve maaşların yüksek olduğu birincil sektöre yönelir. İkincil sektörde meydana gelen boşluk ise göçmenlerle giderilmeye çalışılır (Piore, 1979, s.26-36).

Massey vd., göre, emek arzının demografisi de ikincil piyasanın göçmenlere devredilmesini gerekli kılmaktadır. Modern mesleklerdeki hiyerarşinin en altında bulunan işlerdeki motivasyon eksikliği, düşük ücret, yapısal enflasyon, istikrarsızlık, terfi etme seçeneklerinin azlığı gibi nedenlere bağlı olarak bu tür işlerin iki talibi bulunmaktaydı. Bunlar kadınlar ve gençlerdi. Ancak, kadınların gelirin yanında işlerini bir sosyal statü kariyerine dönüştürerek farklı sektörlerdeki işgücüne daha fazla katılması, boşanmaların artması, örgün eğitimin yaygınlaşması ve doğum oranlarının azalması gibi nedenlere bağlı olarak ikincil sektördeki giriş seviyesindeki işlerin kaynağ değişmiştir. Böylece endüstrileşmiş toplumlarda toplumsal koşullarda meydana gelen dönüşüme bağlı olarak giriş seviyesindeki işlerin kaynağı kadın ve gençlerden göçmenlere doğru kaymıştır. Bu bağlamda ikili iş gücü kuramı, mikro ekonomik kuramcıların savunduğu ilkeleri ne tamamen reddetmekte ne de kabul etmektedir. Çünkü mikro ekonomik kuramcıların savunduğu gibi bireyler rasyonel bir tercihte bulunarak endüstrileşmiş toplumlarda olumsuz özellikler atfedilen ikincil sektördeki işlerde çalışabilirler. Böylece bireyler, istihdam olanağı bulmakta, kazançlarını artırabilmekte ve anavatanlarındaki ailelerinin gelirlerine katkı sunabilmektedir (Massey vd., 1993, s.443-444). 
Abadan-Unat, bu kuramın göçle ilgili temel varsayımlarını şöyle özetlemektedir:

1. Uluslararası nüfus hareketleri, endüstrileşmiş toplumların işgücü talebine göre şekillenir. İşüucü talebi ya doğrudan işverenler tarafından ya da onlar adına hükümetler tarafından belirlenir.

2. Ülkelerarasındaki işgücü ücret farklılığı göç için tek başına yeterli bir koşul değildir. Çünkü göçmen talebi ekonominin yapısal gereksinimlerine göre değil istihdam uygulamalarına göre belirlenir.

3. Bir ülkede esas olarak işgücü ücretlerinin yükselmesi üzerinde belirleyici olan toplumsal ve kurumsal mekanizmalardır. Dolayısıyla bir ülkede yabancı göçmenlerin azalması ücretlerin artması üzerinde çok belirleyici olmamaktadır.

4. Ancak toplumsal ve kurumsal mekanizmalar düşük düzeyli ücretlerin azalması üzerinde çok belirleyici olmamaktadır. Çünkü göçmen işçilerin artması düşük düzeyli ücretlerin daha da düşmesine yol açabilir.

5. Uluslararası göç hareketlerini kontrol etmek için dünya ekonomisinin yapısında bir değişiklik yapmak gerekir. Çünkü göçmenler sanayi sonrası toplumların ekonomilerinin esas unsurunu oluşturmaktadır. Yoksa yerel düzeydeki hükümetlerin ücret ve istihdam ile ilgili almış olduğu kararlar göçü etkilemeyecektir (Abadan-Unat, 2002, s.14).

Bu kuram, uluslararası nüfus hareketini esas olarak ikili iş piyasasına dayandırmaktadır. Ancak endüstrileşmiş ülkelerin ağır sanayiyi ülke d1şına ihraç etmesi, gelişen teknoloji ile birlikte insan emeğine olan ihtiyacın azalması ve daha önce gerçekleşen göçlerle doyuma ulaşması gibi faktörler bu kuramın özellikle çatışma nedenli göçü açıklama potansiyelini kısıtladığı düşünülmektedir. AncakSuriyeli göçmenlerin büyük çoğunluğu, başta Türkiye olmak üzere göç ettiği ülkelerde ikincil sektörlerde kayıt dışı çalışması ve en ucuz emeği oluşturması (Şahankaya Adar, 2018; Lordoğlu ve Aslan, 2015) bu kuramın Suriye göçünü kısmen açıkladığını göstermektedir. Dahası bir taraftan Suriyeli göçmenlerin gelişini engellemeye çalışan Batı ülkelerinin diğer taraftan ikincil sektör ihtiyacını karşılayan 
ve kayıt dışı çalışan binlerce göçmeni göz ardı etmesi bir paradoksu oluşturarak iş gücünün göçmen politikası üzerinde ne kadar belirleyici olduğunu göstermektedir.

\section{Dünya Sistemleri Kuramı}

Wallerstein'a göre, tarihsel süreçte birçok dünya sistemine rastlanmaktadır. Günümüzde dünya üzerinde etkili olan sistem ise modern dünya sistemi ya da kapitalist dünya ekonomisidir. Bu sistem diğer bütün yapılar üzerinde belirleyici olmakta ve dünyaya yön vermektedir Bu bakış açsına göre dünya, esas olarak merkez ve çevre ülkelerden oluşmaktadır. Merkezdeki ülkeler; kapitalist ilişkilerin egemen olduğu, ekonomik açıdan gelişmiş ülkelerdir. Çevredeki ülkeler ise merkezdeki ülkelere bağımlı olan ülkelerdir. Merkez-çevre ülkeler açısından birinin varlığı diğerinin varlığ 1 ile mümkündür (Wallerstein, 2011; 2005). Merkez-çevre kuramina göre çevre ülkeler, merkezdeki ülkelerin sürekli kapitalist gelişimi için gereklidir. Bu bağlamda merkez ülkeler; hammadde, ucuz işgücü ve pazar aç1sindan çevre ülkelere ihtiyaç duyar. Çevre ülkelerden ithal edilen hammadde çevre ülkelerden ithal edilen ucuz işgücü işlenerek kapitalizme geri dönüşüm olarak sağlanır (Çağlayan, 2006, s.80).

Bu bakış açısına göre uluslararası göç 16. yüzyıldan bu yana gelişen dünya pazarının bir sonucudur. Kapitalist toplumların diğer toplumlara müdahalesi neticesinde birçok kişi göç etmeye başlar.. Bu süreç sömürgecilikten bağımsız ele almak mümkün değildir. Çünkü daha önce sömürgeci rejimler kolonyal devletlerin lehine sömürge devletlerinin yoksul bölgelerine girdiği gibi neo-kolonyal hükümetler ve çok uluslu şirketler dünya kapitalistlerin iktidarını devam ettirmek adına aynı misyonu yerine getirmektedir. Bu bağlamda bu yaklaşıma göre nüfus hareketleri, kapitalistleşmenin meydana getirdiği bir durumdur. Kapitalist ekonomi merkezden çevreye genişledikçe kapitalist ekonomiye dâhil olmayan toplumlar da bu sürece dâhil olmaktadır. Bunun sonucunda çevre bölgelerde bulunan hammadde, toprak ve emek dünya pazarına eklemlendikçe göç akımları oluşmakta ve bu göçlerin önemli bir kısmı dış ülkelere yönelmektedir (Massey vd., 1993, s.445; Abadan-Unat, 2002).

Bu kuram uluslararası göç hareketlerini analiz ederken esas olarak ekonomi ve siyasal güç dağılımının eşitsiz biçimine vurgu yapmaktadır. Bu 
bağlamda göç, gelişmiş ekonomik toplumlardaki sermaye sahipleri için bir ucuz işgücü anlamına gelmektedir. Aynı zamanda ülkelerarasındaki ekonomik eşitsizliği derinleştiren bir olgu olarak öne çıkmaktadır. Hatta bu kurama göre göç; sömürgeciliğin bir kalıntısı, bölgesel eşitsizliğin bir sonucu, merkez ülkelerin kapitalizm aracılığıyla sahtekârlıkla oluşturulmuş (vurgu yazara ait) tahakküm ilişkisinin bir yöntemidir. Böylece göç, çevredeki ülkelerin merkezdeki ülkelere bağımlı kalması ve merkezdeki ülkelerin dünya ticaretini kontrol etmesi açısından oldukça önemlidir (Castles ve Miller, 2008, s.35).

$\mathrm{Bu}$ kuram uluslararası nüfus hareketlerinin esas olarak neden meydana geldiğine odaklanmaktadır. Bu bağlamda "Arap Baharı" süreciyle Suriye' de başlayan iç çatışmalar, iç dinamikler neticesinde gelişse de küresel sistemden bağımsız ele alınamaz. Böyle bir sürecin finansal krizin akabinde başlaması ve silah satışlarının küresel kapitalizm açısından memnuniyet verici seviyelere ulaşması şaşırtıcı değildir. Ayrıca Suriye'de başlayan çatışmalar tarihsel bir birikimin neticesidir ve Birinci Dünya Savaşından kalan sorunlardan bağımsız ele alınamaz. Diğer taraftan bir k1sım küresel aktörlerin sürecin başında bir kısım aktörlerin ise daha sonra Suriye krizine müdahil olması Suriye halkının faydası düşündüğünden değil çıkarları doğrultusunda hareket edildiği düşünülmektedir. Dahası Ortadoğu'da ülkelerin sahip olduğu yer altı zenginlikleri bu ülkelerde başlayan çatışmaların ne kadar süreceği üzerinde de belirleyici olmaktadır. Bir çalışma için (İnce, 2018) Suriyeli bir göçmenle yapılan bir görüşmede göçmenin söylediği "Suriye' de kısa zamanda çatışma bitmez. Orada Amerika var, Rusya var. Amerika petrole sahip olmak istiyor, Rusya gaz yataklarına sahip olmak istiyor" şeklindeki sözleri tam da ekonomi ve siyasal güç dağılımının Suriye'deki çatışmaların devamı üzerinde nasıl belirleyici olduğunu göstermektedir. Bu bağlamda göçün nedenlerine odaklanan bu kuram, Suriye göçünün nedenlerinin anlaşılmasında önemli bir katkı sunmaktadır.

\section{Göç Sistemleri Kuramı}

Göç sistemi kurami; ekonomik ve politik temelli olup iki ya da daha fazla ülke arasındaki ilişki ve göç hareketleri arasındaki bağlantısına odaklanır. $\mathrm{Bu}$ teoriye göre ülkelerarasındaki nüfus hareketleri ülkelerarasında daha 
önce var olan ikili ilişkilerin bir devamdır. Bu bağlamda iki ülke arasındaki sömürgeciliğe dayanan tarihsel ilişkiler, siyasal ve ekonomik ilişkiler, kültürel bağlar nüfus alış verişi üzerinde etkili olmaktadır. Göç veren ve alan iki ülke arasındaki mesafe ise bu süreçte çok belirleyici olmamaktadır. Başka bir ifade iki ülke arasındaki göç alışverişi mesafeye göre değil iki ülke arasındaki tarihsel ve güncel ilişkilere göre şekillenmektedir. Meksika ile ABD ve Fransa ile Batı Afrika arasındaki göçmen alış verişi bu çerçevede iyi örnekler oluşturmaktadır (Castles ve Miller, 2008, s.36; Çağlayan, 2006, s.82).

Bu kurama göre göç, makro ve mikro yapıların etkileşiminin bir sonucudur. Makro ve mikro yapılar; göç endüstrisini ortaya çıkaran iş bulma örgütleri, acenteler, kaçakçılar gibi bir dizi aracı mekanizma üzerinden ilişki sağlamaktadır. Makro yapılar; dünya piyasasını belirleyen ekonomi-politiği, ülkelerarası ilişkiler, göç hareketlerini kontrol etme çabaları gibi büyük kuramsal yapılardan oluşmaktadır. Mikro yapılar ise bireyin; göç sürecine dair bilgisi, sahip olduğu ağlar, iş bulma stratejisi, gittiği ülkede uyum becerisi gibi kültürel ve sosyal faktörleri içeren bireysel düzeydeki küçük ölçekli ilişkilerden oluşmaktadır. Daha çok enformel ilişkilere dayalı gelişen mikro yapılar çerçevesinde bireyin göç edecek ülke hakkındaki bilgisi ve kültürel sermayesi göçün başlaması ve devam etmesi üzerinde oldukça etkili olmaktadır. Bu anlamda bireyin sahip olduğu sosyal sermaye unsurlarından biri olan sosyal ağlar, bireyin iş bulma sürecinde ve zor durumlarda karşılıklı yardımlaşmayı teminat altına almaktadır (Castles ve Miller, 2008, s.37). Massey ve Arkadaşları bu kuramın temel varsayımlarını şu şekilde özetlemektedir:

1. Uluslararası göç hareketleri üzerinde asıl belirleyici faktör, göç veren ve göç alan ülkeler arasındaki ekonomik, tarihsel ve siyasal ilişkilerdir. Bu bağlamda göç edilen yer açısından mesafenin göç üzerinde önemli bir etkisi yoktur.

2. Göçmen alan ve veren merkez ve çevre ülkeleri çok kutuplu bir sistemin oluşmasına katkı sunmaktadır.

3. Özellikle göç veren uluslar göç sisteminin birden fazlası üyesi olabilir.

4. Siyasi ve ekonomik koşular değiştiğinde göç sistemleri koşullarla uyumlu bir biçimde evrilir. Bir ulus politik, ekonomik ve sosyal 
değişimlere bağlı olarak göç sistemine dahil olabilir veya ayrılabilir (Massey vd., 1993, s.454).

Göç sistemleri kuramı, Suriyeli göçmenlerin ülke-kent tercihinde ve göç sürecinin açıklanmasında önemli bir açıklama potansiyeli taşıdığı düşünülmektedir. Suriyeli göçmenlerin dünyada en fazla Türkiye'ye sığınması ve Türkiye'de de daha çok sınır bölgelerine yoğunlaşması Türkiye'nin göç politikasının ve fiziksel yakınlığın yanında birçok sosyolojik ve siyasal faktör belirleyici olmuştur. Siyasi, sosyal ve kültürel konular olmak üzere Suriye ve Türkiye arasında birçok konuda birlik ve benzerlik bulunmaktadır. Şu an var olan iki farklı devlet tarihte tek elden, Osmanlı devleti tarafından yönetilmiştir. Suriye'deki Arap, Kürt ve Türk etnisiteye mensup gruplar Türkiye'de de bulunmaktadır. Sınırın iki tarafında kültürler arasında birçok konuda benzerlik ve insanlar arasında akrabalık bağları bulunmaktadır. Bu bağlar çizilen siyasi sınırlara rağmen sınırın iki yakasındaki halklar tarafından sürekli canlı tutularak devam ettirilmiştir. Dolayısıyla birçok konudaki birlik ve benzerlik Suriye göçünün Türkiye'ye yönelmesinde etkili olmuştur. Özellikle sınır bölgesi açısından konu incelendiğinde ortak bir birliğin olması ve yerel toplum ile göçmen toplum arasında yoğun bir iletişimin yaşanması Çağlayan'a göre dünyada ender rastlanan uluslararası bir göç örneğini oluşturmuştur (Çağlayan, 2015, s.200-202). Suriyeli göçmenlerin sınır bölgesi hakkında bilgi sahibi olması, sosyal ve kültürel sermayesi ile sahip olduğu sosyal ağlar özellikle ilk süreç için Türkiye'nin sınır bölgelerine yoğunlaşmasında etkili olmuştur. Diğer taraftan sınır bölgelerinde iş bulma olanağının düşük olması Suriyeli göçmenleri diğer bölgelere yöneltmesine neden olmaktadır (İnce, 2018).

\section{İlişkiler Ağı (network) Kuramı}

İlişkiler ağı göçmenlerin geldikleri ülke, yeni yerleştikleri ülke, eski göçmen, yeni göçmen ve yerleşik halk arasında ortak köken, hemşerilik, soydaşlık ve dostluk gibi kişilerarası bağlantılara referansta bulunan bir kavramdır. Bu ağların ve bağların varlığı uluslararası göçün devamının sağlanmasında belirleyici rol oynamaktadır. Çünkü bu ağlar, göçmenlerin göç etme sürecinden iş bulma sürecine kadar önemli birçok işleve sahiptir (Abadan-Unat, 2002, s.18). 
Sosyal ağlar uluslararası göçün devamı açısından önemli bir kaynak sunar. Çünkü sonradan göç edenler ilk göç edenlere göre daha az riskle karşı karşıyadır ve göç sürecindeki toplam maliyeti daha düşüktür. Bu bağlamda göçmen ağının varlığı göç etmek üzere olanları karar vermede cesaretlendirmekte ve göç sürecindeki işlerini kolaylaştırmaktadır. Aynı zamanda göç edilen ülkede ilişki ağları sayesinde işler daha hızlı yürümektedir. İlişki ağları sadece ekonomik maliyetleri düşürmemekte sosyal maliyetleri de düşürmektedir. İlk göç edenler gelmiş oldukları yabancı toplumda yalnızlık duygusu yaşarken sonradan gelenler sahip olduğu sosyal ilişki ağları sayesinde bu durumdan daha az etkilenmektedir (Çağlayan, 2006, s.86).

Crisp'e göre göçmenlerin sahip olduğu sosyal ağların birçok fonksiyonu bulunmaktadır. Bunlardan bir tanesi sosyal ağlar; göç etmeye karar veren bireyin gitmeyi hedeflediği ülkeye nasıl gidileceğini ve ulaşım ile ilgili detayları, giriş koşullarını, hedeflediği ülkede ve transit ülkelerde s1nır dişı edilme politika bilgisini sağlar. Sosyal ağların diğer bir fonksiyonu, göçmenlerin göç sürecinde maliyetlerin en aza indirilmesi ile ilgili göçmenlere finansman kaynağı sunar. Sosyal ağların diğer bir yönü, özellikle düzensiz bir biçimde dünyanın bir bölgesinden başka bir bölgesine geçmek isteyen kişilere örgütsel alt yapıyı sağlar. Başka bir ifade ile düzensiz göçün alt zemininin hazırlanmasına önemli bir katkı sunar. Sosyal ağların göçmenlere başka bir katkısı, göçmenlerin hedeflediği ülkeye vardıktan sonra yeni düzene alışma ve temel ihtiyaçlarının giderilmesi ile ilgilidir (Crisp, 1999, s.6-7). Bu kuramın temel varsayımları şu şekilde özetlenebilir:

1. Göçmen ve potansiyel göçmenlerin sahip olduğu sosyal ağlar, uluslararası göç hareketlerini artırmakta, potansiyel göçmenleri göç etmeye cesaretlendirmektedir.

2. Göçmenlerin sahip olduğu sosyal ağlar riskleri azaltmakta, ekonomik ve sosyal maliyetleri düşürmektedir. Bu bağlamda uluslararası göçlerde önemli olan göç eden ve göç edilen ülke arasındaki neo-klasik kuramcıların savundu gibi ücret farklılığı değil ilişki ağlarıdır.

3. Sosyal ağlar göç öncesinde, göç aşamasında ve göç ettikten sonra göçmenin dikkat etmesi gerektiği alt yapıyı hazırlar. Özellikle düzensiz göçmenlere bu konuda önemli bilgi sunar. 
4. Sosyal ağlar, göçmenlerin anavatanlarındaki kimliklerini muhafaza etmesine ve yalnızlık düzeyinin düşmesine yardımcı olurken yerel halk ile göçmenler arasındaki bütünleşmeyi zorlaştırmaktadir.

5. Göçmen ağ ilişkileri oluştuktan sonra yeniden üretilir. Bu bağlamda hükümetlerin göçmenlerin sosyal ağlarını kontrol altına alma çabası zorlaşmaktadır.

6. Göçmenler arasındaki sosyal ağlar toplumsal koşularla bağlantılı olarak süreç içinde evrilir ve yeni şekiller alır. Böylece ilişki ağları zamanla kurumsallaşarak bağımsız bir olgu haline gelebilir.

7. Sosyal ağlar, göçmenlerin hedef ülke ve mekân seçimi üzerinde belirleyici olmaktadır. Benzer özelliklere sahip göçmenlerin mekânsal yoğunlaşmasına neden olmaktadır.

Göç sistemi kuramı gibi ağ kuramı da Suriye göçünün yönünün belirlenmesinde açıklayıcı olduğu düşünülmektedir. Suriye göçü bir anda olup biten bir olay değil 2011 yılında başlayıp günümüzde azalsa da Suriye'de meydana gelen gelişmelere paralel, bireysel dönüşümlere bağl1 devam eden bir sürece karşıllık gelmektedir. Başka bir ifade ile Suriye ve diğer ülkeler arasındaki göç trafiği devam etmektedir ve uzun süre de devam edeceği görünmektedir. Çatışmaların başladığı dönemlerde kendi hayatlarını kurtarmak amacıyla bulunduğu konuma en yakın ülkeye göç eden Suriyeliler sonradan göç edecek kişiler için bir kılavuz ve bilgi kaynağ1 olmuştur. Başka bir ifade ile Suriye'den Türkiye'ye göç edip Türkiye'nin farklı illerine yönelen öncü grup sonradan gelişen göçmen ilişki ağının da temelini oluşturmuştur (Çağlayan, 2015, s.203). İlk göç edenlerin göç ettikleri ülkelerdeki durumlarını paylaşması, bulundukları ülkenin Suriyeli göçmene bakışı, sunduğu hizmet ve göç güzergâhı sonradan göç edenlerin ülke tercihi üzerinde belirleyici olmuştur. Aynı ülkede bulunan Suriyeli göçmenler bile bulundukları kentlerin durumlarını birbiriyle paylaşarak göçmenlerin belli kentlere yönelmesinde etkili olmaktadır. İş bulmaktan yalnızlığının hafifletilmesine kadar birçok konuda sosyal ağlar Suriyeli göçmene bir danışmanlık hizmeti sağlamaktadır. Çünkü göç ağları, "göç edenlere sadece hazır göç güzergâhları değil, kurdukları göçmen semt ve bölgelerinde istihdam olanakları, mali ve kültürel birikim de sağlayarak, yerleşme ve göçmen topluluğu içerisinde sosyalleşme olanağ da sunmaktadır" (Özgür Baklacıoğlu, 2010, s.17). Ayrıca "göçmenlerin 
kurdukları iş yerleri, dernekler, kahvehaneler, restoranlar, avukat büroları, doktor muayenehaneleri, dükkânlar vb. yerler yeni gelenlerin iktisadi ve özellikle de kültürel ihtiyaçlarını beslemektedir" (Özgür Baklacıŏlu, 2010, s. 18). Özllikle Suriyeli göçmenlerin yoğunlaştığı bölgelerde bu tür ilişki biçimlerine sıkça rastlamak mümkündür.

\section{Kurumsal Kuram}

Uluslararası göçmenlerin sayısı gün geçtikçe artmaktadır. Ancak uluslararası göçmen alan merkez ülkeler ise gün geçtikçe göçmenlerin gelişini engelleyici bir çaba içine girmektedir. Bu bağlamda ekonomik sermaye açısından güçlü olan devletlerin göçmenlere yönelik talebi bir taraftan azalırken dünyada meydana gelen güncel gelişmelere bağlı olarak potansiyel göçmenlerin sayısı hızla artmaktadır. Bu durumda bazı firmalar uluslararası göç sürecinde büyük rant sağlayarak göç endüstrisine katkı sunmaktadır. Ortaya çıkan bu dengesizlik durumunda göçmenlerin talebini karşılamak için özel kuruluşlar ve gönüllü organizasyonlar da faaliyet göstermektedir. Bu yardım kuruluşları, gelişmiş ülkelerde göç endüstrisinin mağdurları olan, yasa dışı, belgesiz çalışan göçmenlerin koşullarını rehabilite etmek için büyük bir çaba sarf etmektedirler. Bu organizatörler hem göç etme aşamasında hem de göçmenler hedef ülkeye vardıktan sonra göçmenlere birçok konuda yardımcı olmaktadır. Yasal olmayan yollardan göçmenlerin hedef ülkeye ulaşmasını sağlar, iş bulma konusunda aktif rol alır, göçmenlere kalacak yer ayarlayarak destek olur. Sonuç olarak sermaye sahipleri göçmenleri engelleyecek politikalar geliştirirken gönüllü kuruluşlar da göçmen dolaşımı için çaba sarf eder (Massey vd., 1993, s.450-451). Suriye'de güvenliğin hâkim olmaması ve bir kısım Suriyeli göçmenin gitmek istediği Batı Avrupa ülkelerinin Suriyelilerin gelişini engellemeye çalışması göçmenlerin hedef ülkeye ulaşmak için tehlikeli yollara başvurmasına neden olmaktadır. Dahası bu süreçten rant sağlayarak göç sürecini endüstriye dönüştüren kişiler ve gruplar olmaktadır. Hem Suriye'de yol kesenler, göç etmek isteyenlere kendi belirlediği ücreti aldıktan sonra onların geçişine izin vermekte hem de Suriye dışında göçmenleri hedefledikleri ülkelere yasadışı yollarla ulaştıracağını vaat eden organizatörler olmaktadır. Bu kişiler zaten savaş mağduru olan Suriyeli 
göçmenleri bir kez daha mağdur etmektedir. Diğer taraftan Suriyeli göçmenler göç ettikleri ülkelerde başta işsizlik ve kötü çalışma koşulları olmak üzere birçok sorunla karşılaşmaktadır. Bu sömürü düzenini ortadan kaldırmak ya da hiç olmazsa hafifletmek için de bazı sivil toplum örgütleri ve organizatörler göç sürecinde Suriyeli göçmenlere yardımcı olmuş ve olmaya devam etmektedir.

\section{Kümülatif Nedensellik}

Ulusal ve uluslararası göçlere uygulanabilen bu kuram, merkez-çevre ve neo-Marksist gelişim teorisine yakın bir bakış açısı sunmaktadır. Bu bağlamda kümülatif nedensellik kuramı, nüfus hareketlerini ele alırken tarihsel-yapısalcı bir kaynaktan beslenmektedir. Bu yaklaşıma göre göç, sanayileşmiş zengin ülkelere ve kent merkezlerindeki kapitalist sermaye sahiplerine ucuz emek ve diğer kaynakları sağlayarak bölgesel ve ulusal gelişmeye engel olmaktadır. Böylece göç en değerli kaynakları sermaye sahiplerine sunarak asimetrik bir biçimde çevrenin merkeze olan bağımlıl1ğını artırmakta yerel ekonominin gelişmesini baltalamaktadır (De Haas, 2010, s.234).

Massey vd. kümülatif göç biçiminden etkilenen en yaygın bazı sosyoekonomik faktörleri ele almıştır. Bu faktörlerden biri gelirin dağılımdır. $\mathrm{Bu}$ faktör merkezli olarak göç, sadece gelirin artışı amaçlandığında ya da risklerin farklılaşması durumunda meydana gelmemektedir. Hane halk1nın gelir dağılımı da göç üzerinde belirleyici olmaktadır. Birkaç haneden birkaç kişi göç ettiğinde göç eden hanelerin geliri yükselmektedir. Bu durumda haneler arasında gelir eşitsizliği ve göreceli yoksulluk artmaktadır. Bu durum, diğer hanelerden de kişilerin göç etmesini motive etmektedir. Diğer bir faktör toprak dağılımıdır. Göç edenler genellikle yatırımlarını toprak alarak değerlendirmektedir. Ancak ücretli çalışmayı toprağı işlemeye tercih ederek toprağı nadasa bırakmaktadır. Böylece toprağın olduğu bölgelerde tarımsal işgücüne olan talep azalarak diğer insanların göç etmesine neden olmaktadır. Toprağı işleseler bile bu kişiler genellikle modern araçları kullanacağından dolayı işgücüne olan talep yine azalacak ve göçü etkileyecektir. Göç kültürünün oluşması da göçün artışını etkilemektedir. Göç eden kişi sayısı artıkça ve göç yaygınlaştıkça davranış ka- 
lıpları da değişmektedir. Bu bağlamda daha iyi bir yaşam ve göç arasındaki ilişki algısı güçlendikçe daha fazla insan göç etmektedir. Göçü artıran diğer bir sosyo-ekonomik faktör beşeri sermayedir. Gelişmiş ülkeler beşeri sermayeye sahip bireyleri kendi ülkelerine çekmeye çalışmaktadır. Bu durumda beşeri sermaye açısından güçlü bireyler göç ettiği ülkede üretime büyük katkı sunarken gelindiği ülke bu açıdan daha da yoksullaşmaktadır. Göçü besleyen diğer bir faktör de bazı mesleklerin göçmen mesleği olarak toplum tarafından damgalanmasıdır. Bu damgalama, göçmenleri bu mesleklere kanalize edilmesine yardımcı olurken yerel halkın bu mesleklerden kaçınmasını beraberinde getirmektedir (Massey vd., 1993, s.451-453).

Kümülatif nedensellik kuramı da daha önce değinilen birçok kuram gibi göçün daha çok ekonomik bileşenine odaklanmaktadır. Ancak yine de göç kültürünün oluşması ve beşeri sermayenin analizi Suriye göç sürecine katkı sunmaktadır. Çatışmalarla birlikte Suriye' den diğer ülkelere göçün başlaması geride kalan kişilerin de göç etmesini teşvik etmiştir. Komşu ülkelere göç eden beşeri sermayesi yüksek Suriyeli göçmenlerin üçüncü ülkelere göç etmesi de bu kuramın Suriye göç sürecini açıklamasına katkı sunduğu görülmektedir.

\section{Sonuç}

Uluslararası göçün zamanla değişik formlar alması göçü açıklayan kuramların da değişmesine neden olmaktadır. Dahası uluslararası göç zamanla homojen bir yapıdan heterojen bir yapıya dönüşmektedir. İş gücü göçmenlerine sı̆̆ınmacılar ve düzensiz göçler gibi göç türleri dâhil olarak uluslararası göç küreselleşmeyle eklemlenerek kaotik bir hal almaktadır. Şirin Öner'e (2012, s.13) göre uluslararası göç; dinamik, karmaşık ve çok boyutlu bir olgu olması farklı bağlamlarda, farklı formlarda gelişmesine neden olmaktadır. Uluslararası göç, içinde bulunduğu konjonktüre bağlı olarak farklı şekillerde gelişmekte ve konjonktürün değişmesi ile birlikte göç süreci de etkilenerek dönüşmektedir. Bu bağlamda Suriye gücünün nedenleri, süreci ve sonuçları göç kuramları açısından değerlendirildiğinde her bir göç kuramının açılama biçiminin Suriye göçünü açıklamada yetersiz kaldığı görülmektedir. Suriye göçünün çok boyutlu olması, 
zorunlu göçmenlerin yanında ekonomik sebeplerden göç edenlerin olması, farklı dönemlerde gerçekleşen göçlerin farklı özellikler barındırması ve göçmenlerin birçok bakımdan birbirinden farklılaşması kuramların bu göç olgusunu açıklamasını zorlaştırmaktadır.

Erbaş'a göre ise (1999, s.31-32) uluslararası göçü genel geçer önermelerle çözümlemek mümkün değildir. Çünkü farklı ülkelerden aynı ülkeye göç eden farklı gruplar farklı ilişki biçimlerini geliştirebildiği gibi aynı ülkeden göç eden gruplar da farklı ilişki biçimlerini geliştirebilmektedir. Bu farklı ilişki biçimlerinin çözümlenmesi göç eden ve edilen toplum ve topluluk arasında özgün koşulların etkileşiminin analizi ile mümkün olabilmektedir. Suriyeli göçmenler de göç ettikleri ülkelerde farklı etkiler oluşturmaktadır. Suriyeli göçmenlerin daha az göç ettiği Avrupa ülkelerinde daha fazla gündem oluşturmakta ve özellikle kültürel farklılıklar bu konuyla ilgili tartışmaları tahrik etmektedir. Bu bağlamda yakın gelecekte Suriyeli göçmenlerin göç ettiği ülkelerin göç politikaları Suriyeli göçmenlerin gelecekte ne tür bir sosyal ilişki geliştirebileceği üzerinde etkili olacaktır.

Sirkeci'ye göre nüfus hareketliliğinin gerçekleşebilmesi için göç etmek isteyen bireyin göç etme imkânına sahip olması gerekir. Bu imkânlar; göç etme bilgisi, sosyal ağlar ve finansal sermayeden oluşmaktadır. Öncelikle göç edecek kişinin nasıl göç edeceği ve göç etme sürecinde hangi yöntemi kullanacağı bilgisine sahip olması gerekir. Bu süreçte daha önce göç deneyimine sahip olan dostlar, akrabalar ve tanıdıklar önemli bir kaynak olarak ortaya çıkmaktadır. Bu kaynak sadece göç sürecinde değil göç ettikten sonra da göç eden kişi veya kişilerin alışma sürecine de yardımcı olmaktadır. Diğer bir göç etme imkânı maddi kaynaklara karşılık gelmektedir. Kısacası Sirkeci'ye göre bu kaynağa sahip olup da göç etmek isteyen göç edebilir, aksi taktirde göç etmesi çok zordur. Çatışmaların meydana geldiği bölgelerde de bu kaynaklar açısından güçlü olan bireyler ilk önce göç etmektedir (Sirkeci ve Bardakçı, 2016, s.538). Bu bakış açısı Suriye göçünün açıklanmasına önemli bir katkı sunmaktadır. Çünkü Suriye'de çatışmalar başladığı ilk süreçte ekonomik, sosyal ve beşeri sermayesi yüksek kişilerin daha önce göç ettiği bilinmektedir (İnce, 2018). Üçüncü bir ülkeye, özellikle Avrupa ülkelerine göç eden Suriyeli göçmenlerin de bu kaynaklar açısından zengin olan kişiler olduğu anlaşılmaktadır. 
Günümüzde göç türlerinin çoğalması, çatallaşması ve her göç olgusunun biricik olması nedeniyle tek bir kuramla nüfus hareketlerini analiz etmek mümkün olmadığı gibi nüfus hareketleri arasında ortak özellikler de bulunmaktadır. Bu ortak özellikler Erbaş'ın (2018) ifadesi ile "emperyalizm", "kapitalizmin işleyiş̧i" ve "sömürü" gibi uluslararası ekonomipolitiğinin göç süreçleri ve yönleri üzerinde belirleyici olmasıdır. Başka bir ifade ile uluslararası göç bu unsurlardan bağımsız düşünülemez. Bu bağlamda Suriye göçüne neden olan çatışmaları Suriye tarihinden ve küresel aktörlerin Suriye ile ilgili emellerinden bağımsız analiz etmek de mümkün değildir.

Abadan-Unat'a (2002, s.2003-2004) göre göç sürecinde meydana gelen konjonktür değişikliğine bağlı olarak göç üzerinde yapılan çalışmaların ilgi alanları da değişmiş ve kullandıkları yöntemler farklılaşmıştır. İkinci dünya savaşından sonra yeniden bir yapılanma içerisine giren göç alan ülkeler ikili anlaşmalar çerçevesinde diğer ülkelerden işgücü göçü talebinde bulunmuştur. Dolaysıyla bu dönemde ekonomik unsur ön plana çıkmış ve bu konu üzerinde araştırma yapanlar maliyet-kazanç kuramı ile göç olgusunu açılamaya çalışmıştır. 1970'lerde ise göçmenlerin daimi yerleşimciler haline gelmeye başlaması ile ilgi alanları asimilasyon, uyum ve bütünleşme gibi konulara kaymıştır. 1980'lerde de ilgi odağı etnik adalar, kolektif örgütlenmeler ve göçmenlerin ilişki biçimleri olmuştur. Daha sonra Komünist rejimlerin yıkılması, Avrupa'daki paradigma değişikliği, ulus ötesi örgütlerin artışı, bazı ulus-devletlerin parçalanması ve Sovyet Birliğinin dağılması uluslararası göç alanına yeni boyutlar kazandırdı. Bununla birlikte ulaşım ve iletişim alanında meydana gelen baş döndürücü gelişmeler, etnik ve dinsel ilişki ağları, piyasanın yayılması, ideolojik örgütlenmeler uluslararası göç alanında yapılan araştırmalarda kullanılan kavram ve kuramların çeşitlenmesine yol açtı. Suriye göçünde olduğu gibi Ortadoğu ve diğer coğrafyalardaki çatışmalar zorunlu göçün artışına yol açmaya devam etmektedir. Sonuç olarak göç sonucunda meydana gelen birçok problemi çözüme kavuşturmanın en önemli bileşenlerden birinin çatışmanın ve göçün diğer nedenlerini ortadan kaldırılması ile mümkün olabileceği görülmektedir. 


\section{EXTENDED ABSTRACT}

\section{An Evaluation On Migration Theories and Syrian Migration

\section{Celal İnce}

Bitlis Eren University

International migration continues to set the world agenda in terms of both its causes and the outcomes of its sociological and political aspects. Economic differences between regions, poverty, civil wars, political transformations, deterioration of ecological balance and many other factors caused migration of many people in the 21st century and it seems that this phenomenon will remain dynamic in the future. On the other hand, international immigration deeply affects both immigrant-sending and immigrant-receiving countries. In addition, migration has many effects on economy, politics, social and cultural areas. Moreover, the most affected ones are displaced persons during the forced migration process. In this context, international migration comes to the forefront as a basic fact that needs to be researched in different disciplines. In particular, the reasons for the mass migrations from Syria to other countries as a result of the internal conflicts in recent years, encourage comprehensive investigation of the migration process and the sociological consequences. In this study, the aim is to analyze Syrian migration process in terms of the migration theories.

It is generally possible to deal with the issue of international migration in terms of liberalism, realism, nominalist, Marxist approach, determinist, capital raising approach, humanist approach and micro, meso, macro evaluations. When the issue is viewed from the aspect of liberalism, it is seen that liberalism has not directly developed an approach for international migration, refugees, displaced persons or stateless persons. But there are mechanisms that it has developed throughout he course of events (Çelebi, 2011). Nominalist approach, on the other hand, makes an 
analysis of asylum seekers and other immigrants, based on factors such as restrictive migration policies of states, domestic market and racism (Çelebi, 2011; Black, 1991). Marxist view emphasizes that the migration phenomenon is a structural consequence of the capitalist system (Çam, 2014, p.20-1; Bal et al., 2012, p.194). According to this view, international migration analysis can only be possible by explaining the relationship between labor and capital with the reconstruction of capitalism on a global scale (Erbaş, 2002).

International migration can be analysed on micro, meso and macro scales. According to the the micro analysis, people migrate to places where their relatives live or places that are familiar to them. Meso analysis claims that immigrants compare the conditions of the country in which they live in and of the country to which they will migrate and decide accordingly. Macro analysis, on the other hand, asserts that migration occurs in cases where population is high and employment is low. While determinist approaches focus on the qualities of immigrants, capital raising approach makes an analysis focusing on wages. Humanist approach analyses the decision an individual makes on expatriating (Parnwell, 2006; Faist, 2000).

Two phases might be emphasised while analysing Syria migration in terms of migration theories. One of the phases is reasons and actors of the Syrian migration and the other one is migration process and the analysis of the sociological consequences of the migration. In this context, the realist approach, which focuses on the determinant conditions in cases where immigrants become refugees, offers an important perspective for the Syrian migration. This pragmatic view that prioritizes interests and power preference of states causes the migration to continue and become an area of exploitation by providing a basis for conflicts in Syria to become chronic (Babahanoğlu and Bilici, 2018). According to Ravenstein (1885, 1889), one of the basic principles of migration is that it occurs within short range. As in many forced migration cases, majority of Syrian immigrants migrated to neighboring countries. Physical distance, poverty of immigrants, the possessed cultural capital and the migration policies of target countries have been effective in this process. According to the theory of push and pull factors (Lee, 1966), when Syrian migration is considered, there are many push factors, and there are many pull factors regarding the 
target country. The primary push factors are safety and public life destroyed by safety concerns (unemployment, poverty etc.). The primary pull factors regarding Turkey are safety, physical proximity, migration policy, business opportunity and cultural resemblance. As factors such as conflict, poverty, unemployment support each other, economy theories(macro and micro theories of neoclassic economy, new economy theories, segmented labor market, world-systems theory) have a potential to explain the Syrian migration as well. Historical and cultural unity and resemblances between Turkey and Syria are among the factors that have caused Syrians to mostly migrate to Turkey (Çağlayan, 2015). In this context, migration systems theory also explains the Syrian migration to some extent. The network theory also contributes to the explanation of country and city preferences of Syrians who migrate to another country.

In conclusion, different forms that international migration takes in time, causes theories explaining the migration phenomenon to change. In this context, when the reasons, process and consequences of Syrian migration are considered in terms of migration theories, it is obvious that each form of explanation falls short of explaining the Syrian migration in its entirety. That the Syrian migration is multidimensional, that there are people migrating on economic grounds along with forced immigrants, that different migrations at different times have different traits and that immigrants differ from each other in many respects make it difficult for the theories to explain this migration phenomenon. Due to increases in migration types, their complicated structures and uniqueness of each migration phenomenon at the present time, it is not possible to analyse population movements with only one theory and there are also common traits between population movements. These common traits show that international political economics such as "imperialism", "operation of capitalism" and "exploitation" are determinant regarding migration phases and directions according to Erbaş (2018). 


\section{Kaynakça / References}

Abadan-Unat, N. (2002). Bitmeyen göç: Konuk işçilikten ulus-ötesi yurttaşlı̆̆a. İstanbul: Bilgi Üniversitesi Yayınları.

AFAD. (2014). Suriye'den Türkiye'ye nüfus hareketleri: Kardeş topraklarındaki misafirlik. Ankara: AFAD, www.afad.gov.tr

Babahanoğlu, V. ve Bilici, Z. (2018). Realizm versus idealizm: göç, bölgesel barış ve istikrar düşmanı mı? Uluslararası Sosyal Araştırmalar Dergisi, 11(61), 734-740.

Bal, H., Aygül, H. H., Oğuz, Z. N., ve Uysal, M. T. (2012). Göçle gelenlerin toplumsal sorunları: Isparta örneği. Süleyman Demirel Üniversitesi Fen Edebiyat Fakültesi Sosyal Bilimler Dergisi, 27, 191-210.

Black, R. (1991). Refugees and displaced persons: Geographical perspectives and research directions. Progress in Human Geography, 15(3), 281-298.

Castles, S. M. ve Miller, M. J. (2008). Göçler çağı: Modern dünyada uluslararası göç hareketleri (Çev: B. U. Bal ve İ. Akbulut). İstanbul: İstanbul Bilgi Üniversitesi Yayınları.

Crisp, J. (1999). Policy challenges of the new diasporas: Migrant networks and their impact on asylum flows and regimes. Geneva: UNHCR.

Çağlayan, S. (2006). Göç kuramları, göç ve göçmen ilişkisi. Sosyal ve Beşeri Bilimler Araştırmaları Dergisi, 17, 67-91.

Çağlayan, S. (2015). Suriye savaşı ve Suriyeli göçmenler: Teorik ve kavramsal anlama çabası. Sosyoloji Divanı, (6), 193-208.

Çam, F. (2014). Avrupa Birliği göç politikaları: Makedonya, Bulgaristan, Türkiye. Ankara: Alter Yayınları.

Çelebi, Ö. (2011). Kuramların sessizliğii: Liberalizm, realizm ve iltica rejiminin kuruluşu. Ö. Çelebi, S. Özçürümez ve Ş. Türkay (Der.), $\dot{l} l-$ tica, uluslararası göç ve vatansızlık: Kuram, gözlem ve politika içinde (s. 9-26). Ankara: UNHCR

De Haas, H. (2010). Migration and development: A theoretical perspective. International migration review, 44(1), 227-264.

Elma, F. ve Şahin A. (2015). Suriye'den Türkiye'ye göç ve açı̆̆a çıkan temel sorun alanları. Turkish migration conference 2015 selected proceedings içinde (s.430-439). London: Transnational Press London. 
Erbaş, H. (1999). Metodoloji tartışmaları ışığında göç ve etnisite. Sosyolojisi Dergisi, 2, 17-39.

Erbaş, H. (2002). Küresel kriz ve marjinalleşme sürecinde göç ve göçmenler. Doğu-Batı, 18, 173-193.

Erbaş, H. (2018). Suçlular/nedenler, mağdurlar ve biz: Göç ve göçmenliğe tarihsel ve bütüncül bir bakış. 29th International Congress on Creative Drama in Education, 25-28 October 2018 Ankara/TURKEY

Erdoğan, M. (2015). Türkiye'deki Suriyeliler: Toplumsal kabul ve uyum. İstanbul: İstanbul Bilgi Üniversitesi Yayınları.

Faist, T. (2000). The volume and dynamics of international migration and transnational social spaces. Oxford: Oxford University Press.

İnce, C. (2018). Uluslararası göç bağlamında Türkiye'deki Suriyeli göçmenlerin mekânsal yoğunlaşması. İksad Publishing House. Erişim: https://docs.wixstatic.com/ugd/614b1f_2a6698ecca984bd6a0a89d84607a0d4a.pdf

Kapu, H. (2012). TRA2'de göç olgusu: sebep ve sonuçlar bağlamında analitik bir araştırma. Kars: T.C. Serhat Kalkınma Ajansı.

Kaya, M. (2017). Türkiye'deki Suriyeliler iç içe geçişler ve karşılaşmalar. İstanbul: Hiperlink Yayınları.

Kaynak, S., Arslan, İ., Alancıoğlu, E., ve Koçakoğlu, M. A. (2016). Göçün sosyo-ekonomik sonuçları: Suriyeli göçmenler üzerine bir uygulama. A. Diken ve A. Buluş (Eds.). 2. Uluslararası Uygulamalı Bilimler Kongresi: "Göç, Yoksulluk ve İstihdam", 23-25 Eylül 2016, Konya, Türkiye, Bildiriler içinde (s. 11-18). Konya: Necmettin Erbakan Üniversitesi Uygulamalı Bilimler Yüksek Okulu.

Lee, E. S. (1966). A theory of migration. Demography, 3(1), 47-57.

Lordoğlu, K ve Aslan, M. (2015). Araştırma-saha notları: Beş Sınır kenti ve işgücü piyasalarında değişim: 2011-2014 [Labour markets in the five border provinces]. Göç Dergisi, 2(2), 249-267.

Massey, D. S. (1999). Why does immigration occur?: A theoretical synthesis. Hirschman, P. Kasinitz and J. DeWind (Eds.), The handbook of international migration: The American experience içinde (s. 3452). New York: Russell Sage Foundation.

Massey, D. S., Arango, J., Hugo, G., Kouaouci, A., Pellegrino, A., ve Taylor, J. E. (1993). Theories of international migration: A review and appraisal. Population and development review, 19(3), 431-466. 
Özgür Baklacıoğlu, N. (2010). Dış politika ve göç: Yugoslavya'dan Türkiye'ye göçlerde Arnavutlar (1920-1990). İstanbul: Derin Yayınları.

Özkarslı, F. (2014). Suriye'den Türkiye'ye göç ve Suriyelilerin enformel istihdamı (Mardin örneği). (Yayınlanmamış yüksek lisans tezi). Artuklu Üniversitesi Sosyal Bilimler Enstitüsü, Mardin.

Parnwell, M. (2006). Population movements and the third world. USA: Routledge Introductions to Development.

Piore, M. J. (1979). Birds of passage: Migrant labor and industrial societies. Cambridge: Cambridge University Press.

Ravenstein, E. G. (1885). The laws of migration. Journal of the Statistical Society of London, 48(2), 167-235.

Ravenstein, E. G. (1889). The laws of migration. Journal of The Royal Statistical Society, 52(2), 241-305.

Robinson, R. (2005). Beyond the state-bounded immigrant incorporation regime. Transnational migrant communities: Their potential contribution to canada's leadership role and influence in a globalized world. Ottawa: The North-South Institute.

Sirkeci, İ., ve Bardakçı, S. (2016). Suriye'den gelenler misafir değil bir göç kültürünün öncüleri. Humanitas-Uluslararası Sosyal Bilimler Dergisi, 4(7), 531-544.

Somuncu, B. (2006). Türkiye'nin Avrupa Birliği'ne tam üyelik sürecinde uluslararası göç politikası. Yayınlanmamış yüksek lisans tezi. Dokuz Eylül Üniversitesi, Sosyal Bilimler Enstitüsü, İzmir

Stark, O., ve Bloom, D. E. (1985). The new economics of labor migration. The American Economic Review, 75(2), 173-178.

Şahankaya Adar, A. (2018). Türkiye'de yeni prekarya Suriyeli işgücü mü?. Calisma ve Toplum, 56(1), 13-36.

Şahin, A. (2015). Suriyeli sı̆̆ınmacıların Kahramanmaraş çadır kent'te yaşam koşulları ve adaptasyon sorunları. Yayınlanmamış yüksek lisans tezi. Kahramanmaraş Sütçü İmam Üniversitesi Sosyal Bilimler Üniversitesi, Kahramanmaraş.

Şirin Öner, N. A. (2012). Göç çalışmalarında temel kavramlar. S. G. Ihlamur-Öner ve N. A Şirin Öner (Der.), Küreselleşme çağında göç: Kavramlar, tartışmalar içinde (s. 13-27). İstanbul: İletişim Yayınları.

Uluslararası Göç Örgütü (IOM). (2009). Göç terimleri sözlü̆̆̈ü. Cenevre, İsviçre: Uluslararası Göç Örgütü Yayını. 
Wallerstein, I. (2005). Dünya sistemleri analizi, bir giriş (Çev: E. Abadoğlu ve N. Ersoy). İstanbul: Aram Yayıncılık.

Wallerstein, I. (2011). Dünya sistemleri analizi (Çev: E. Abadoğlu). İstanbul: BGST Yayınları.

Yalçın, C. (2004). Göç sosyolojisi. Ankara: Anı Yayıncılık.

Kaynakça Bilgisi / Citation Information

İnce, C. (2019). Göç kuramları ve Suriye göçü üzerine bir değerlendirme. OPUS-Uluslararası Toplum AraştırmalarıDergisi,11(18), 2579-2615. DOI: 10.26466/opus.546737 